\title{
Bibliometrics indicators in the Caribbean islands: French West Indies authorship analyzed from 1989 to 2018
}

\author{
CEDRIC CONTARET ( $\square$ cedric.contaret@gmail.com ) \\ Centre Hospitalier Universitaire de Martinique \\ Raymond CESAIRE \\ Centre Hospitalier Universitaire de Martinique \\ Jacqueline DELOUMEAUX \\ Centre Hospitalier Universitaire Pointe-a-Pitre Abymes \\ Rémi NEVIERE \\ Centre Hospitalier Universitaire de Martinique \\ Dabor RESIERE \\ $\mathrm{CHU}$ de Martinique \\ André CABIE \\ Centre Hospitalier Universitaire de Martinique \\ Emmanuelle SYLVESTRE \\ Centre Hospitalier Universitaire de Martinique \\ Clarisse JOACHIM \\ Centre Hospitalier Universitaire de Martinique \\ Moustapha DRAME \\ Centre Hospitalier Universitaire de Martinique
}

Research

Keywords: cooperation, caribbean, bibliometrics, research

Posted Date: December 19th, 2019

DOl: https://doi.org/10.21203/rs.2.19311/v1

License: (a) (i) This work is licensed under a Creative Commons Attribution 4.0 International License. Read Full License 


\section{Abstract}

Background

Bibliometrics are mathematical methods used in various scientific domains to measure scientific output based on the number of publications, the prestige of the journal, and the number of citations of the research after its publication. To the best of our knowledge, only a few bibliometric studies have been performed in the Caribbean or the French West Indies. The aim of this study was to quantify the collaborations and scientific output between the two university teaching hospitals of Martinique and Guadeloupe, at the regional, national and international level.

Method

A bibliometrics analysis was performed from the international databases Web of Science and PubMed, for the period from 1989 to 2018 inclusive (30 years). Three types of bibliometric indicators were used, namely quantitative indicators, performance indicators, and organisation-specific indicators. Affiliations of the first and last authors were identified from PubMed. Between 2014 and 2018, we recorded the affiliations of all authors (from the first to the last author) who collaborated on an article with the University Hospital of either Martinique of Guadeloupe

Results

Between 1989 and 2018, a total of 1,522 indexed articles were published with at least one author affiliated to either the University Hospital of Martinique $(\mathrm{N}=827)$ or the University Hospital of Guadeloupe $(\mathrm{N}=685)$. The majority of articles for both hospitals were in category Q1 (35.8\% for Martinique, and 35.2\% for Guadeloupe). In Martinique, over the last 30 years, the 3 main research areas have been clinical neurology, ophthalmology and surgery, together representing $28.7 \%$ of all research areas, with the highest number of articles published in the field of clinical neurology ( $\mathrm{n}=81$ ). In the University Hospital of Guadeloupe, the area of hematology was largely represented, with 79 articles published. For both hospitals, the first and last authors of the articles published were mainly from mainland France, and from either Martinique or Guadeloupe university hospital

Conclusion

This quantitative and qualitative analysis shows the development of medical and scientific research in Martinique and Guadeloupe over the last three decades, as well as the extent of their collaborative partnerships at national and international level.

\section{Background}

Bibliometrics are mathematical methods used in various scientific domains to measure scientific output based on the number of publications, the prestige of the journal, and the number of citations of the research after its publication $(1,2)$. Several recent bibliometric studies have evaluated scientific repercussions or temporal trends in different areas of scientific and medical research (3). Other studies have focused on the impact of publication output of one or several institutions $(4,5)$ or at a national level $(6)$. To the best of our knowledge, only a few bibliometric studies have been performed in the Caribbean or the French West Indies(7, 8).

For more than 30 years, national plans have been implemented in France to develop research within French hospitals, including in the regions of Guadeloupe and Martinique (French West Indies, FWI). These two regions are not geographically located in Europe, but rather, are situated in the Caribbean. University teaching hospitals were set up in 1985 in Guadeloupe and in 1986 in Martinique. The implementation of successive programmes to boost attractiveness and to support emerging research teams has culminated in the existence of several research units that are certified by the French Ministry for Research and Higher Education (9), which are a rich breeding ground for research in these two regions. Indeed, the Caribbean zone presents several specific epidemiological features that represent major public health issues. Due to their geographical position, the FWI are exposed to severe climatic conditions that promote emerging vector-borne diseases (Chikungunya, dengue, Zika), as well as being exposed to meteorological phenomena such as earthquakes and hurricanes. Hurricanes have become more frequent, and increasingly severe in recent years. There is therefore a compelling need for close cooperation between Caribbean countries to face these threats. Furthermore, the burden of chronic diseases (obesity, diabetes, cancer) is growing, and at the origin of substantial morbidity (10). Populating ageing is another major preoccupation for both islands, and is a priority topic for research, with the planned constitution of population cohorts in the coming years $(11,12)$.

Taken together, these specificities of the FWI underscore the importance of medical and scientific cooperation between Caribbean countries, and the need for a concerted effort between the ministries of health and research in neighbouring countries, which should be facilitated by Martinique and Guadeloupe's recent joining of the Organisation of Eastern Caribbean States (OECS), in 2015 and 2019 respectively (13).

To date, to the best of our knowledge, no bibliometric study has investigated scientific collaboration between the various academic institutions of the FWI and their scientific output. Given the specific epidemiological characteristics of Martinique and Guadeloupe, it would be interesting to assess the development of research in these two regions. The aim of this study was therefore to quantify the collaborations and scientific output between the two university teaching hospitals of Martinique and Guadeloupe, at the regional, national and international level.

\section{Methods}

We performed a bibliometrics analysis from the international databases Web of Science and PubMed, for the period from 1989 to 2018 inclusive (30 years). All original research articles, reviews, letters, editorials and comments were selected; other publication types were excluded. 
To search for publications involving the University Hospital of Martinique and/or the University Hospital of Guadeloupe, we used InCites, an analytical tool developed and marketed by Clarivate Analytics (14) that aggregates summary measures of scientific output and citations at the level of countries, organisations and specific disciplines. An organization enhanced feature available in the Web of Science allows the user to search by an organization name that has been unified, to yield comprehensive and specific search results. More than 215 different search terms were thus used by InCites in search engines for these searches.

Three types of bibliometric indicators were used, namely quantitative indicators, performance indicators, and organisation-specific indicators. The quantitative indicator was the number of publications per five-year period, to measure scientific output in each hospital by type of publication. Performance indicators were: (1) the quality of publications, as measured by the average journal impact factor; and (2) the average number of citations of the article per five-year period. The "Top 1\%" and "Top 10\%" indicators systematically provided by InCites were also used to identify the most highly cited articles at international level. The Journal Citation Reports were used to rank journal by quartiles of impact factor, with journals in Q1 (i.e. the top $25 \%$ ) corresponding to the most widely cited journals in the field.

Organization-specific indicators, also known as structural indicators, were used to measure connections between publications, authors, and research fields. To estimate the structural indicators, the full set of data for each article identified was extracted from PubMed (15).

Affiliations of the first and last authors were identified from PubMed. Each affiliation thus identified was classed by country. Martinique, Guadeloupe as well as French Guiana, Reunion island, Mayotte and French Polynesia were all identified with codes distinct from that of metropolitan France, to make it possible to distinguish them and compare with mainland France.

Between 2014 and 2018, we recorded the affiliations of all authors (from the first to the last author) who collaborated on an article with the University Hospital of either Martinique of Guadeloupe. For authors with several affiliations, the hospital affiliation was retained.

Results are presented in table format for quantitative and qualitative indicators, and in graphical format for organisation-specific indicators. Data were extracted in XML format from PubMed and analysed using SAS version 9.4 (SAS Institute Inc., Cary, NC).

\section{Results}

Between 1989 and 2018, a total of 1,522 indexed articles were published with at least one author affiliated to either the University Hospital of Martinique (N = 827) or the University Hospital of Guadeloupe $(\mathrm{N}=685)$.

For both hospitals, there was a steady increase in the number of articles published over the years, reaching a peak in the most recent period (i.e. 2014-2018, with 348 articles for the University Hospital of Martinique and 292 for Guadeloupe).

Quantitative indicators are presented in Table 1. Almost $80 \%$ of publications were original research articles in both hospitals. For Martinique, the proportion of articles in journals ranked in the top two quartiles increased steadily, from $21.4 \%$ and $10.7 \%$ respectively in the first 5 -year period, to $40.0 \%$ and $25.1 \%$ in the last 5-year period. The majority of articles for both hospitals were in category Q1 (35.8\% for Martinique, and 35.2\% for Guadeloupe). 
Table 1

Overall description of the bibliometrics indicators of scientific output for the University Hospital of Martinique and the University Hospital of Guadeloupe,

from 1989 to 2018

\begin{tabular}{|c|c|c|c|c|c|c|c|c|c|c|c|c|c|c|}
\hline & \multicolumn{7}{|c|}{ Martinique } & \multicolumn{7}{|c|}{ Guadeloupe } \\
\hline & Total & $\begin{array}{l}1989- \\
1993\end{array}$ & $\begin{array}{l}1994- \\
1998\end{array}$ & $\begin{array}{l}1999- \\
2003\end{array}$ & $\begin{array}{l}2004- \\
2008\end{array}$ & $\begin{array}{l}2009- \\
2013\end{array}$ & $\begin{array}{l}2014- \\
2018\end{array}$ & Total & $\begin{array}{l}1989- \\
1993\end{array}$ & $\begin{array}{l}1994- \\
1998\end{array}$ & $\begin{array}{l}1999- \\
2003\end{array}$ & $\begin{array}{l}2004- \\
2008\end{array}$ & $\begin{array}{l}2009- \\
2013\end{array}$ & $\begin{array}{l}2014- \\
2018\end{array}$ \\
\hline $\begin{array}{l}\text { Number of } \\
\text { articles }\end{array}$ & 837 & 38 & 86 & 100 & 108 & 157 & 348 & 685 & 24 & 67 & 77 & 88 & 137 & 292 \\
\hline $\begin{array}{l}\text { Original } \\
\text { research } \\
\text { article }\end{array}$ & 651 & 27 & 65 & 86 & 88 & 129 & 256 & 548 & 15 & 52 & 55 & 80 & 115 & 231 \\
\hline Letter & 89 & 5 & 14 & 11 & 8 & 13 & 38 & 84 & 6 & 8 & 15 & 5 & 12 & 38 \\
\hline Review & 44 & 1 & 0 & 2 & 8 & 6 & 27 & 22 & 0 & 0 & 4 & 2 & 5 & 11 \\
\hline Editorial & 42 & 1 & 0 & 1 & 4 & 9 & 27 & 23 & 0 & 2 & 3 & 1 & 5 & 12 \\
\hline Comment & 11 & 4 & 7 & 0 & 0 & 0 & 0 & 8 & 3 & 5 & 0 & 0 & 0 & 0 \\
\hline $\begin{array}{l}\text { IF } \\
\text { (Median; IT) }\end{array}$ & $\begin{array}{l}2.56 \\
3.19\end{array}$ & $\begin{array}{l}1.96 \\
2.45\end{array}$ & $\begin{array}{l}1.16 \\
1.51\end{array}$ & $\begin{array}{l}1.54 \\
2.58\end{array}$ & $\begin{array}{l}2.44 \\
3.10\end{array}$ & $\begin{array}{l}2.56 \\
2.84\end{array}$ & $\begin{array}{l}2.77 \\
3.10\end{array}$ & $\begin{array}{l}2.42 \\
3.06\end{array}$ & $\begin{array}{l}2.55 \\
1.94\end{array}$ & $\begin{array}{l}1.79 \\
2.67\end{array}$ & $\begin{array}{l}2.17 \\
3.40\end{array}$ & $\begin{array}{l}2.30 \\
4.46\end{array}$ & $\begin{array}{l}2.19 \\
2.96\end{array}$ & $\begin{array}{l}2.76 \\
3.20\end{array}$ \\
\hline $\begin{array}{l}\text { Time Cited } \\
\text { (Median;IT) }\end{array}$ & $\begin{array}{l}4.00: \\
12.00\end{array}$ & $\begin{array}{l}3.00 \\
15.00\end{array}$ & $\begin{array}{l}5.00: \\
9.00\end{array}$ & $\begin{array}{l}7.50 \\
18.00\end{array}$ & $\begin{array}{l}8.00 \\
25.00\end{array}$ & $\begin{array}{l}7.00 \\
17.00\end{array}$ & $\begin{array}{l}2.00 \\
6.00\end{array}$ & $\begin{array}{l}6.00 \\
13.00\end{array}$ & $\begin{array}{l}3.00 \\
14.00\end{array}$ & $\begin{array}{l}8.00 \\
14.00\end{array}$ & $\begin{array}{l}8.00 \\
17.00\end{array}$ & $\begin{array}{l}10.00 \\
18.00\end{array}$ & $\begin{array}{l}6.00 \\
14.00\end{array}$ & $\begin{array}{l}3.00 \\
8.00\end{array}$ \\
\hline Q1 (\%) & 35.82 & & 21.43 & 24.44 & 35.00 & 37.32 & 40.00 & 35.23 & & 34.78 & 37.1 & 31.08 & 26.61 & 40.41 \\
\hline Q2 (\%) & 21.19 & & 10.71 & 17.78 & 20 & 17.61 & 25.16 & 20.83 & & 17.39 & 14.52 & 24.32 & 22.58 & 20.82 \\
\hline Q3 (\%) & 12.24 & & 32.14 & 15.56 & 8 & 10.56 & 11.61 & 19.32 & & 21.74 & 22.58 & 17.57 & 19.35 & 18.78 \\
\hline Q4 (\%) & 30.75 & & 35.72 & 42.26 & 37 & 34.51 & 23.23 & 24.62 & & 26.09 & 25.81 & 27.03 & 31.45 & 20 \\
\hline $\begin{array}{l}\text { TOP } 10 \% \\
(\%)\end{array}$ & 10.56 & 5.26 & 6.02 & 8 & 7.48 & 10.83 & 13.79 & 10.06 & 15 & 3.39 & 6.85 & 6.25 & 9.09 & 13.48 \\
\hline TOP 1\% (\%) & 2.04 & 0 & 0 & 4 & 0 & 1.91 & 2.87 & 0.93 & 0 & 1.69 & 0 & 0 & 0 & 1.77 \\
\hline
\end{tabular}

Figure 1 presents the number of articles published by research area over the study period for the two hospitals, with authors in first or last position. In Martinique, over the last 30 years, the 3 main research areas have been clinical neurology, ophthalmology and surgery, together representing $28.7 \%$ of all research areas, with the highest number of articles published in the field of clinical neurology $(n=81)$. In the University Hospital of Guadeloupe, the area of hematology was largely represented, with 79 articles published. There was a substantial increase in the number of articles published in the most recent 5year period, in the area of infectious diseases for Guadeloupe, and in the field of public, environmental and occupational health for Martinique, with the number of articles multiplied by 2 and 1.5 respectively between 2014 and 2018 . Only the most widely represented 12 research areas are shown in the figure. The remaining 60 research areas are detailed in the Supplementary table for both hospitals.

Figure 2 illustrates the five most frequently represented countries among the affiliations of the first authors, and among the affiliations of the last authors, for the articles attributed to the University Hospital of Guadeloupe, and for those attributed to the University Hospital of Martinique over the last 30 years. For both hospitals, the first and last authors of the articles published were mainly from mainland France, and from either Martinique or Guadeloupe university hospital. In articles attributed to Guadeloupe, the first author was actually from Guadeloupe in $65.8 \%$ (420 authors) and the last author in $56.3 \%$ $(\mathrm{N}=359)$. In Martinique, the distribution was similar, with $55.8 \%$ of first authors from Martinique $(\mathrm{N}=440)$, and $49.6 \%$ last authors $(\mathrm{N}=391)$. During the most recent 5-year period of the study, there was a net increase in the number of first and last authors from mainland France in articles from both hospitals: from 2009-2013 to 2014-2018, there was a 2.86-fold increase in the number of authors from mainland France in publications from Martinique, and a 2.91fold increase in publications from Guadeloupe, versus 1.68-fold and 1.85-fold increases for authors originating from Martinique and Guadeloupe respectively.

Detailed analysis of the bibliographic metrics is shown in Table 2. For both hospitals, the average number of authors per article was lower when an author from that hospital was first or last author. The average number of authors per article was highest when the first or last author was from mainland France. 
Analysis of the affiliations of authors in all articles published from 2014 to 2018

\begin{tabular}{|c|c|c|c|c|c|c|c|c|c|c|c|}
\hline & & \multicolumn{5}{|c|}{ Martinique (Number of articles : 348 ) } & \multicolumn{5}{|c|}{ Guadeloupe (Number of articles : 292) } \\
\hline & & \multicolumn{5}{|l|}{ Affiliations } & \multicolumn{5}{|l|}{ Affiliations } \\
\hline \multirow{3}{*}{$\begin{array}{l}\text { Total } \\
\text { number } \\
\text { of } \\
\text { authors }\end{array}$} & & $\begin{array}{l}\text { Mainland } \\
\text { France }\end{array}$ & Martinique & Guadeloupe & USA & $\begin{array}{l}\text { French } \\
\text { Guiana }\end{array}$ & $\begin{array}{l}\text { Mainland } \\
\text { France }\end{array}$ & Guadeloupe & Martinique & USA & $\begin{array}{l}\text { French } \\
\text { Guiana }\end{array}$ \\
\hline & $\mathrm{n}(\%)$ & $\begin{array}{l}2159 \\
(54.7)\end{array}$ & $\begin{array}{l}1020 \\
(25.84)\end{array}$ & $\begin{array}{l}124 \\
(3.14)\end{array}$ & $\begin{array}{l}115 \\
(2.9)\end{array}$ & $\begin{array}{l}91 \\
(2.3)\end{array}$ & $\begin{array}{l}1496 \\
(50.3)\end{array}$ & $\begin{array}{l}967 \\
(32.5)\end{array}$ & $\begin{array}{l}122 \\
(4.1)\end{array}$ & $\begin{array}{l}66 \\
(2.2)\end{array}$ & $\begin{array}{l}64 \\
(2.15)\end{array}$ \\
\hline & $\begin{array}{l}\text { Mean } \\
(\mathrm{SD})\end{array}$ & $23 \pm 15$ & $10 \pm 7$ & $19 \pm 15$ & $17 \pm 6$ & $15 \pm 6$ & $25 \pm 20$ & $10 \pm 7$ & $15 \pm 10$ & $12 \pm 8$ & $13 \pm 7$ \\
\hline \multirow{4}{*}{$\begin{array}{l}\text { First } \\
\text { authors }\end{array}$} & & \multicolumn{5}{|l|}{ Affiliations } & \multicolumn{5}{|l|}{ Affiliations } \\
\hline & & $\begin{array}{l}\text { Mainland } \\
\text { France }\end{array}$ & Martinique & USA & Guadeloupe & $\begin{array}{l}\text { French } \\
\text { Guiana }\end{array}$ & Guadeloupe & $\begin{array}{l}\text { Mainland } \\
\text { France }\end{array}$ & Martinique & USA & $\begin{array}{l}\text { French } \\
\text { Guiana }\end{array}$ \\
\hline & $\mathrm{n}(\%)$ & $\begin{array}{l}163 \\
(47.0)\end{array}$ & $\begin{array}{l}132 \\
(38.0)\end{array}$ & $\begin{array}{l}10 \\
(2.9)\end{array}$ & $\begin{array}{l}9 \\
(2.6)\end{array}$ & $\begin{array}{l}8 \\
(2.3)\end{array}$ & $\begin{array}{l}141 \\
(48.3)\end{array}$ & $\begin{array}{l}108 \\
(37.0)\end{array}$ & $\begin{array}{l}10 \\
(3.4)\end{array}$ & $\begin{array}{l}12 \\
(3.6)\end{array}$ & $\begin{array}{l}6 \\
(2.05)\end{array}$ \\
\hline & $\begin{array}{l}\text { Mean } \\
(\mathrm{SD})\end{array}$ & $14 \pm 11$ & $7 \pm 5$ & $19 \pm 9$ & $10 \pm 7$ & $13 \pm 4$ & $7 \pm 4$ & $14 \pm 12$ & $14 \pm 11$ & $9 \pm 6$ & $11 \pm 3$ \\
\hline \multirow{5}{*}{$\begin{array}{l}\text { Last } \\
\text { authors }\end{array}$} & & \multicolumn{5}{|l|}{ Affiliations } & \multicolumn{5}{|l|}{ Affiliations } \\
\hline & & $\begin{array}{l}\text { Mainland } \\
\text { France }\end{array}$ & Martinique & Guadeloupe & UK & USA & Guadeloupe & $\begin{array}{l}\text { Mainland } \\
\text { France }\end{array}$ & Martinique & $\begin{array}{l}\text { French } \\
\text { Guiana }\end{array}$ & USA \\
\hline & $\mathrm{n}(\%)$ & $\begin{array}{l}168 \\
(48.4)\end{array}$ & $\begin{array}{l}121 \\
(34.9)\end{array}$ & $\begin{array}{l}12 \\
(3.5)\end{array}$ & $\begin{array}{l}11 \\
(3.2)\end{array}$ & $\begin{array}{l}9 \\
(2.6)\end{array}$ & $\begin{array}{l}148 \\
(50.7)\end{array}$ & $\begin{array}{l}102 \\
(34.9)\end{array}$ & $\begin{array}{l}6 \\
(2.0)\end{array}$ & $\begin{array}{l}8 \\
(2.7)\end{array}$ & $\begin{array}{l}7 \\
(2.4)\end{array}$ \\
\hline & $\%$ & 48.41 & 34.87 & 3.46 & 3.17 & 2.59 & 50.68 & 34.93 & 2.05 & 2.74 & 2.40 \\
\hline & $\begin{array}{l}\text { mean } \\
(\mathrm{SD})\end{array}$ & $14 \pm 11$ & $7 \pm 5$ & $8 \pm 4$ & $10 \pm 11$ & $16 \pm 6$ & $7 \pm 4$ & $15 \pm 13$ & $10 \pm 5$ & $10 \pm 3$ & $10 \pm 7$ \\
\hline \multicolumn{12}{|c|}{$\begin{array}{l}\text { Total number of authors : total number of authors from each of the five most frequently represented countries in the affiliations of all authors from all } \\
\text { publications from the University Hospital of Martinique (Left panel, } N=348 \text { ) and Guadeloupe (right panel, } N=292 \text { ). }\end{array}$} \\
\hline \multicolumn{12}{|c|}{$\begin{array}{l}\text { First authors: Among the first authors of all publications from Martinique }(\mathrm{N}=348) \text { or Guadeloupe }(\mathrm{N}=292) \text {, the five most frequently represented } \\
\text { countries are listed, with the number of authors from each, and the average number of authors on the publication with the first author is from the } \\
\text { country cited. }\end{array}$} \\
\hline
\end{tabular}

\section{Discussion}

Over the last 30 years, the scientific output of the University Hospitals of Martinique and Guadeloupe has increased steadily. The increase in the number and quality of publications over the last 3 decades was particularly marked in the last 5-year period of the study (2014-2018). This could be due to the implementation of local policies promoting research, or to the increase in the number of physicians with academic teaching positions in both regions, thanks to the creation of the Faculty of Medicine in the French West Indies in 2001. Furthermore, advances in medicine and technological innovation are also factors that should be taken into account in the booming research activity at a national scale. With the help of various programmes implemented by the Ministry of Higher Education \& Research to restructure research activities in France, successive strategic plans have led to the emergence of centres of excellence, in which research and public health issues are the foundation for their work in advancing the state of knowledge. Previous studies have also reported a strong increase in the number of scientific articles published in recent years in large institutions $(4,5)$.

Analysis of the position of each author signing the publications is an indicator of the level of involvement of the various research teams in the work. This simple indicator reveals that when authors from Martinique and/or Guadeloupe are in first or last position, then the average number of authors from both sites in relatively low. Collaborations with authors from other countries could help to increase the number of citations per article, thereby markedly increasing the visibility of the publications $(16,17)$.

In the period from 2014 to 2018, the proportion of authors from the Caribbean islands was low, at around 4\%o in collaboration with the University Hospital of Martinique, and $9 \%$ with the University Hospital of Guadeloupe. Yet, public health problems that are common to all the Caribbean islands are a strong impetus for scientific cooperation that feature in the public health strategic plans laid down by the Carribean Public Health Agency (CARPHA) (18) and regional health authorities (19).

Creating research consortia that comprise researchers from different research institutes could help them to mutually contribute to advancing scientific knowledge specific to their geographical area. Several cooperative initiatives in oncology have been reported in recent publications, leading to the set up of a consortium bringing together Puerto Rico, Cuba and Martinique for the surveillance of cancer through population-based registries (20). In terms of the environment, the recent sargassum seaweed invasion along the coasts of the Caribbean islands (21) could prompt international pluridisciplinary collaboration(22). 
In Guadeloupe, drepanocytosis is the historical research topic, bolstered by the presence of both a national reference centre, and the presence of a national INSERM research unit in Guadeloupe. Collaborations initiated across the Caribbean through the formation of CAREST, the Caribbean Network of Researchers on Sickle Cell Disease and Thalassemia, and with certain African countries, are starting to pay dividends in terms of scientific publications. The topic of cardiovascular and metabolic diseases, both prevalent problems in Guadeloupe and Martinique (e.g. type 2 diabetes, hypertension, chronic renal insufficiency) was long epitomized by a hospital-based research team that made a significant contribution to the visibility of this theme through scientific publications in reputed journals. Over the last decade, the problem of environmental pollution from pesticides has attracted an INSERM unit to set up in Guadeloupe focusing on the topic of health, environment and work. Collaborations with local teams have also been prolific in terms of number of publications. Finally, more recently, the major upsurge in emerging infectious diseases, notably epidemics of Chikungunya and Zika virus, have propulsed the French West Indies to centre stage in terms of research, and boosted the number of scientific publications with international collaborations. This wide spectrum of research areas in these two regions needs to be supported by strong research institutions, working in synergy, to meet the challenges of the island context and relatively small population basins.

Since 2008, in both Guadeloupe and Martinique University Hospitals, new organisational structures for the promotion of research have been put in place, such as the Delegation for Clinical Research \& Innovation (Délégations de la Recherche Clinique et de l'Innovation, DRCI), Clinical Investigation Centres, and centres for biological resources. These new structures have been a major driving force behind the local development of research activities. The DRCl's purpose is to provide support on a daily basis for all those involved in developing research projects, from the conception of the idea, and writing of the protocol, through submission to calls for projects at regional, interregional and European level, and right up to publication of the final results, with staff members specialised in maximising output and impact. The aim is to be capable of competing for large-scale financing programmes, such as the French government's national programme for hospital research (Programme hospitalier de recherché Clinique, PHRC), or European Union funds allocated to research, training and development.

Among the factors that need to be taken into account, it is necessary to consider the amount of time that healthcare professionals have available to engage in research. Indeed, in such ultra-peripheral regions as Martinique and Guadeloupe, the attractiveness of the healthcare environment for professionals is lower, and there is high staff turnover and geographical isolation, factors that all have negative repercussions on research efforts within the hospital in these regions. The unfavourable state of the medical demographics is at the root of the severe difficulties experienced in implementing and sustaining research projects. Indeed, it is not just a question of initiating projects on research areas of interest, but they must also be brought to a successful conclusion, and achieve appropriate publication and visibility.

In view of the size of the population, with an estimated 770,000 inhabitants as of 1 January 2016 in Martinique and Guadeloupe together (23), the level of technical equipment also has to take account of the critical mass of patients necessary to maintain certain medical specialty services, or to render further investment and development viable. Specialties that are offered in these two regions therefore develop in synchrony, working in complementarity as regards the healthcare opportunities on offer in each island (specialists, number of positions, and technical equipment). As a result, which disciplines will produce scientific publications is often a question of the geographical location of the experts in that particular field. This explains the predominance of certain research themes across the two regions.

However, it is noteworthy that the success of clinical research also depends on the inclusion of a suitably large number of patients, in order to ensure adequate statistical power to meet the study's objectives. A population basin with a low number of eligible patients jeopardizes the success of research projects, and therefore, scientific collaboration with partners from the Caribbean who could include patients in large-scale clinical trials would clearly be a fruitful strategy for the development of research activities in this region.

The main partner for both Guadeloupe and Martinique university hospitals over the last 30 years has been mainland France. The participation of both islands in publications reporting multicentre projects led by teams from metropolitan France is very frequent, not to say the majority of publications for the University Hospital of Martinique in the last 5 years. This type of collaborative partnership ensures better visibility, and provides an opportunity to get experience of innovative, large-scale projects, which is an asset in terms of partnership potential. The hospitals of Guadeloupe and Martinique thus work mainly with a partner situated around $8,000 \mathrm{~km}$ away, and work considerably less with their geographically closer Caribbean neighbours, who share similar demographic characteristics.

Regarding the types of research projects carried out in each of the two hospitals studied, access to funding relies on the availability of permanent research teams, as their durability over time is a key factor in successfully completing and publishing research. The recent developments in the university organisation in the French West Indies led to the emergence of research programmes headed by national teams, and which allowed for the inclusion of patients from the West Indies. Progressively, research teams within the Guadeloupe and Martinique hospitals were thus able to develop their own research topics, with their hospitals starting to act as sponsor for new studies. This increase in the number of studies sponsored by the hospitals of Martinique and Guadeloupe subsequently led to the initiation of multicentre projects at national and international level, in a positive knock-on effect.

A potential limitation of this study is that it does not take account of possible explanatory factors such as human relations, which can underpin the initiation of cooperative projects. It would have been interesting to conduct a survey among the healthcare professionals in both institutions investigating the barriers and facilitating factors for scientific research between the two regions, in order to get a broader understanding of the factors influencing publication strategies in both hospitals.

In terms of future perspectives, the dissemination of our findings among the university hospital research teams will be an essential step in understanding how to work towards more collaborative partnerships in the future. Among the possibilities for cooperation, participating in European partnership programmes such as ERDF or ETC (e-health CARES 2014-2020) gives improved visibility to our islands' ability to lead operational projects on topics such 
as the healthcare pathway, access to technological innovation, or e-health. The research areas targeted by these programmes are issues that are common to the whole region, or that aim to exploit the specificities of the region, and public health is one of these. It therefore behoves the research teams in both Martinique and Guadeloupe to demonstrate unequivocally their ability to rise to the strategic challenge of research and innovation.

\section{Conclusions}

To the best of our knowledge, this is the first study to perform a bibliometric analysis of the scientific output of the French West Indies over a period of 30 years. This quantitative and qualitative analysis shows the development of medical and scientific research in Martinique and Guadeloupe over the last three decades, as well as the extent of their collaborative partnerships at national and international level. Our findings shed light on some shortfalls, namely the need to implement more joint cooperative projects in order to join forces in facing up to the growing burden of chronic and emerging diseases, whose prevalence is high in the Caribbean. In the long term, integrating bibliometric indicators into routine practice would make it possible to closely monitor research and innovation strategies across these two regions. Future investigations in this area could focus on analysis of clinical trials reported at national and international level, to assess the level of involvement of the French West Indies, and help to better define objectives for future collaborations and publications.

\section{Abbreviations}

\section{CAREST}

the Caribbean Network of Researchers on Sickle Cell Disease and Thalassemia;

CARPHA

the Caribbean Public Health Agency;

DRCI

Delegation for Clinical Research \& Innovation;

ERDF

European Regional Development Fund;

ETC

European Territorial Cooperation (ETC)

FWI

French West Indies

INSERM

National Institute of Health and Medical Research;

OECS

Organisation of Eastern Caribbean States;

PHRC

French government's national programme for hospital research;

XML

Extensible Markup Language;

\section{Declarations}

Ethics approval and consent to participate : Not applicable.

Consent for publication : Not applicable.

Availability of data and materials : Not applicable

Competing interests : The authors declare that they have no competing interests.

Funding : Not applicable

Authors' contributions : CC was a major contributor in writing the manuscript, made substantial contributions to conception and design, or acquisition of data, or analysis and interpretation of data; and agreed to be accountable for all aspects of the work in ensuring that questions related to the accuracy or integrity of any part of the work are appropriately investigated and resolved. JC, MD,EM,JD reviewed it critically for important intellectual content. RC made substantial contributions to conception and design; been involved in drafting the manuscript and reviewed it critically for important intellectual content. All authors read and approved the final manuscript.

\section{Acknowledgements}

The authors gratefully acknowledge the two university teaching hospitals of Martinique and Guadeloupe. We thank Fiona Ecarnot, MSc (EA3920, University Hospital Besancon, France) for editorial assistance.

\section{References}


1. Pritchard A. Statistical Bibliography or Bibliometrics? Journal of Documentation. 1969 01/01;25:348-9.

2. Durieux V, Gevenois PA. Bibliometric indicators: quality measurements of scientific publication. Radiology. 2010 May;255(2):342-51. PubMed PMID: 20413749. Epub 2010/04/24. eng.

3. Devos P, Menard J. Bibliometric analysis of research relating to hypertension reported over the period 1997-2016. Journal of hypertension. 2019 May 6. PubMed PMID: 31136459. Epub 2019/05/29. eng.

4. Baudoin L, Akiki V, Magnan A, Devos P. [Publication output of French university hospitals during 2006-2015: Trends and position in the national health research landscape]. Presse medicale (Paris, France : 1983). 2018 Nov - Dec;47(11-12 Pt 1):e175-e86. PubMed PMID: 30389213. Epub 2018/11/06. Production scientifique des CHU-CHR en 2006-2015: evolutions et positionnement national. fre.

5. Blanc E, Boulieu R, Bertram D. Bibliometrics and French healthcare institutions from 2004 to 2014. Bulletin du cancer. 2019 Mar;106(3):226-36. PubMed PMID: 30509682. Epub 2018/12/05. eng.

6. Mansoori P. 50 years of Iranian clinical, biomedical, and public health research: a bibliometric analysis of the Web of Science Core Collection (19652014). Journal of global health. 2018 Dec;8(2):020701. PubMed PMID: 30140437 . Pubmed Central PMCID: PMC6076565 at www.icmje.org/coi_disclosure.pdf (available on request from the corresponding author), and declares no conflict of interest. Epub 2018/08/25. eng.

7. Barreto SM, Miranda JJ, Figueroa JP, Schmidt MI, Munoz S, Kuri-Morales PP, et al. Epidemiology in Latin America and the Caribbean: current situation and challenges. International journal of epidemiology. 2012 Apr;41(2):557-71. PubMed PMID: 22407860. Pubmed Central PMCID: PMC3324459. Epub 2012/03/13. eng.

8. Silva H, Kleinstiver S, Sungar E, Rubin R, Hernández-Hernández R, Pulido P, et al. Trends, challenges and promotion of clinical and cardiovascular research in Latin America and the. Prevention and Control. 2006 09/01;2.

9. Antilles Ud. Structures de recherche. 2019.

10. CEPIDC. Interroger les données de mortalité. 2019:https://www.cepidc.inserm.fr/causes-medicales-de-deces/interroger-les-donnees-de-mortalite.

11. INSEE. Seniors en Martinique : Un enjeu économique. 2016 22/09/2016:https://www.insee.fr/fr/statistiques/2128984.

12. Organization PAH. FRENCH GUIANA, GUADELOUPE, AND MARTINIQUE Overall Context. 2015:https://www.paho.org

13. States OoEC. Organization of Eastern Caribbean States OECS. 2019:https://www.oecs.org/. Epub 24/2/17.

14. Clarivate I. Available at: https://clarivate.com/products/incites.

15. PubMed. Available at: https://www.ncbi.nlm.nih.gov/pubmed.

16. Katz J, Hicks D. How much is a collaboration worth? A calibrated bibliometric model. Scientometrics. 1997 11/01;40:541-54.

17. Wagner CS, Park HW, Leydesdorff L. The Continuing Growth of Global Cooperation Networks in Research: A Conundrum for National Governments. PloS one. 2015;10(7):e0131816. PubMed PMID: 26196296. Pubmed Central PMCID: PMC4510583. Epub 2015/07/22. eng.

18. Carpha. Research Training and Policy Development. 2019:http://carpha.org.

19. Guadeloupe A. Collaboration Projets interreg. 2019:https://pressroom.oecs.org/cooperation-medicale-dans-la-caraibe--les-professionnels-de-sante-fontle-point-sur-lavancee-du-projet-interreg-cares.

20. Joachim C, Veronique-Baudin J, Vinh-Hung V, Contaret C, Macni J, Godaert L, et al. Building capacity for cancer surveillance and public health research: The Cancer Task Force Project for Cooperation in the Caribbean and Aging Research. Journal of global health. 2019 Dec;9(2):020304. PubMed PMID: 31360443. Pubmed Central PMCID: PMC6642813 www.icmje.org/coi_disclosure.pdf (available on request from the corresponding author), and declare no competing interests. Epub 2019/07/31. eng.

21. Resiere D, Valentino R, Neviere R, Banydeen R, Gueye P, Florentin J, et al. Sargassum seaweed on Caribbean islands: an international public health concern. Lancet (London, England). 2019 Dec 22;392(10165):2691. PubMed PMID: 30587359. Epub 2018/12/28. eng.

22. Resiere D, Mehdaoui H, Neviere R, Megarbane B. Sargassum invasion in the Caribbean: the role of medical and scientific cooperation. Revista panamericana de salud publica $=$ Pan American journal of public health. 2019;43:e52. PubMed PMID: 31171924. Pubmed Central PMCID:

PMC6548073. Epub 2019/06/07. eng.

23. https://www.insee.fr/en. Statistics. 2016.

\section{Figures}



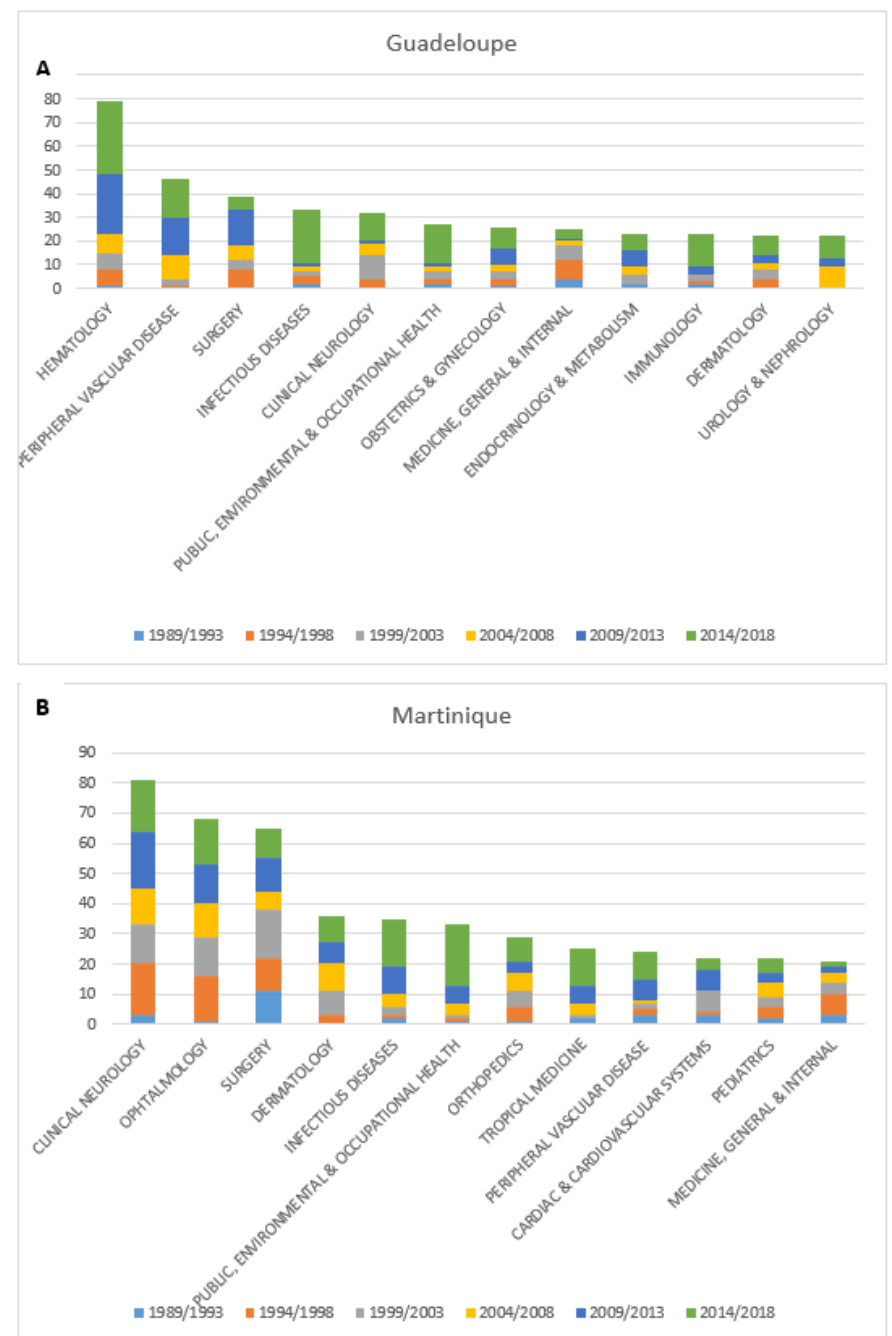

\section{Figure 1}

Distribution of articles published by the University Hospital of Guadeloupe (panel A) and Martinique (panel B) by research area, from 1989 to 2018 

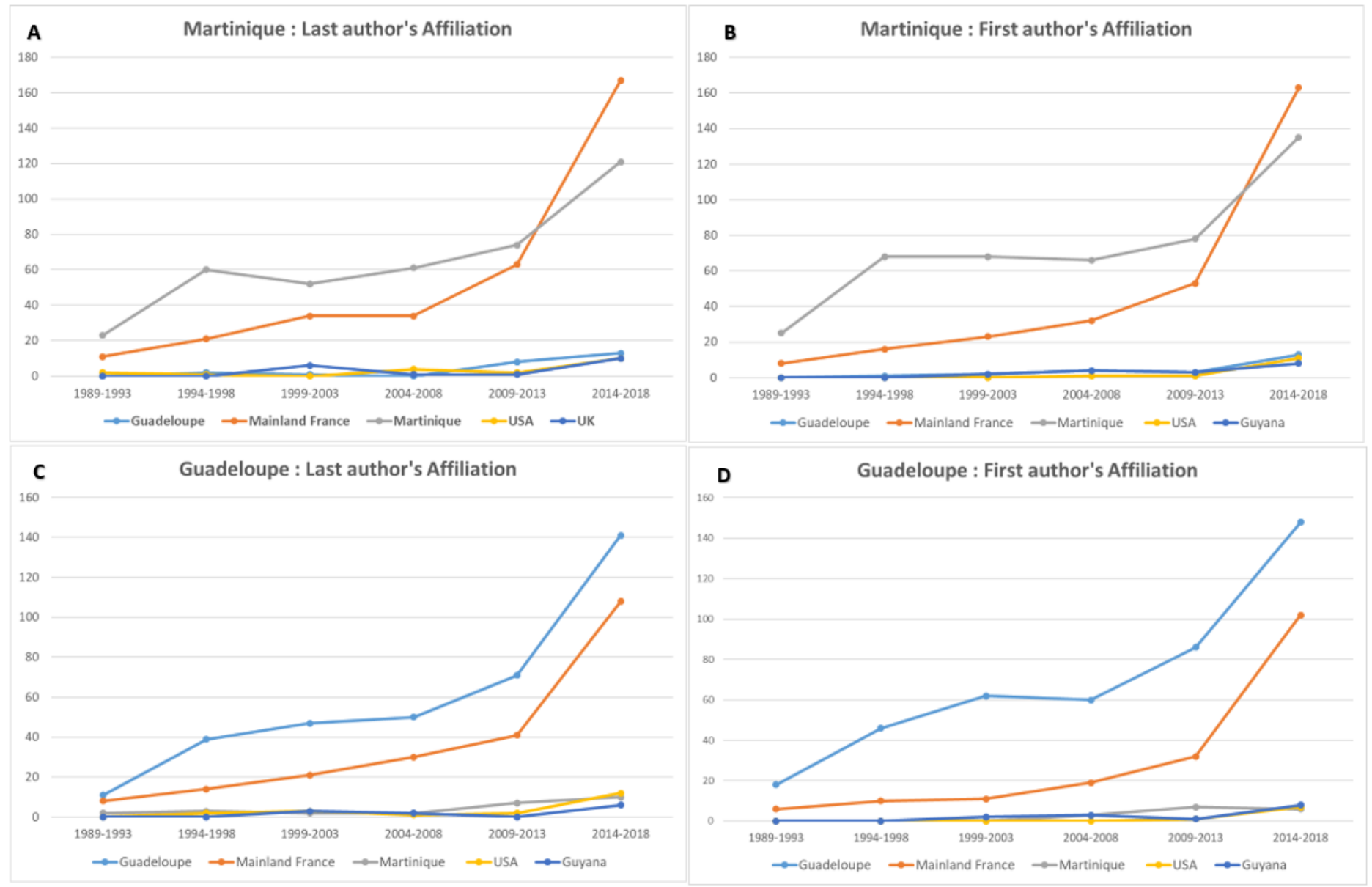

\section{Figure 2}

Evolution of the number of articles according to the ranks of authors in Martinique ( $A$ and $B)$ and in Guadeloupe (C and D)

\section{Supplementary Files}

This is a list of supplementary files associated with this preprint. Click to download.

- additionnalfile1.docx 